\title{
Homeobox Protein Hox-C5
}

National Cancer Institute

\section{Source}

National Cancer Institute. Homeobox Protein Hox-C5. NCI Thesaurus. Code C124123.

Homeobox protein Hox-C5 (222 aa, $\sim 25 \mathrm{kDa}$ ) is encoded by the human HOXC5 gene.

This protein plays a role in the modulation of anterior-posterior axis formation. 